\title{
Was the Increase in Shrimp Biomass on the Northeast Newfoundland Shelf a Consequence of a Release in Predation Pressure from Cod?
}

\author{
G. R. Lilly, D. G. Parsons and D. W. Kulka \\ Department of Fisheries and Oceans \\ P. O. Box 5667, St. John's, Newfoundland, Canada A1C 5X1
}

\begin{abstract}
Biological changes in the ecosystem of the Northeast Newfoundland Shelf during the late1980s and 1990s included a collapse in the biomass of cod (Gadus morhua), a substantial increase in the biomass of northern shrimp (Pandalus borealis), and an expansion in the area fished for shrimp. The timing and magnitude of changes in cod biomass and the quantity of shrimp consumed by cod were explored to determine if they were consistent with the hypothesis that the increase in shrimp biomass was a consequence of a reduction in predation pressure from cod. Results are equivocal because the timing of both the increase in the shrimp stock and the decline in the cod stock remain unclear and there is considerable uncertainty in the estimates of consumption of shrimp by cod. Nevertheless, it appears that an initial increase in shrimp biomass must have occurred during the early to mid-1980s and was not related to changes in the cod, whereas a larger increase in shrimp biomass in the 1990 s was related at least in part to the collapse of the cod.
\end{abstract}

Keywords: biomass, cod, predation, Newfoundland Shelf, shrimp

\section{Introduction}

The shelf ecosystem off southern Labrador and northeastern Newfoundland (Northwest Atlantic) changed dramatically during the late-1980s and early1990 s, with numerous species experiencing changes in abundance, distribution and timing of migrations (Atkinson, 1994; Gomes et al., 1995; Narayanan et al., 1995; Montevecchi and Myers, 1996). Prominent among these changes was a collapse of the Div. $2 \mathrm{~J}+3 \mathrm{KL}$ stock of cod (Gadus morhua) and an apparent surge in the biomass of northern shrimp (Pandalus borealis), hereinafter referred to simply as shrimp. The extent to which the trends in these two populations are related is not known.

The two species may have responded in opposite directions to some environmental influence. For example water temperatures on the shelf off Labrador and Newfoundland were below normal from the early1980 s to the mid-1990s, with particularly cold periods in the early- to mid-1980s and early-1990s (Drinkwater, 1996; Colbourne et al., 1997). Parsons and Colbourne (2000) constructed a predictive model for relative shrimp abundance off Labrador that incorporated a time series of winter ice cover and supported the hypothesis that cold conditions are favourable for shrimp survival at early life-history stages. The role of cold water in the collapse of the cod is controversial. Some authors (e.g. Hutchings and Myers, 1994) have concluded that the cold water had no role in the collapse, whereas others (e.g. Rose et al., 2000) have presented evidence that the cod shifted southward, partly in response to the cold, and thereby became more vulnerable to Canadian and international fisheries. In addition, a decline in individual growth rate associated with cold water (Shelton et al., 1999) contributed to a decline in productivity and there is a possibility that natural mortality increased as a consequence of stress attending a reduction in feeding opportunity, as postulated for cod in the northern Gulf of St. Lawrence (Dutil et al., 1999; Dutil and Lambert, 2000).

Alternatively, shrimp and cod may have negatively affected one another through predation at various stages in their life cycles. The possibility of predation by shrimp on the eggs or larvae of cod lies largely within the realm of speculation. However, predation by cod on demersal stages of shrimp has been well documented, not only off Labrador (Bowering et al., MS 1983) and eastern Newfoundland (Lilly, 1991) but also in waters off West Greenland (Sidorenko, 1962) 
and Iceland (Magnússon and Pálsson, 1989) and in the Barents Sea (Mehl, 1989). Similarly, predation by Pacific cod (Gadus macrocephalus) on shrimp has been documented in the Gulf of Alaska (Albers and Anderson, 1985).

Negative associations between shrimp and cod have been reported from several geographic areas. For example, in the waters off West Greenland, the decline of the cod stock in the late-1960s was postulated to be connected to the rapid development of the offshore shrimp fishery and the size of the shrimp resource in the mid-1970s (Carlsson and Smidt, 1978). In Icelandic waters, there was a negative correlation between the abundance of shrimp and the abundance of juvenile cod (Jakobsson and Stefánsson, 1998; Stefánsson et al., 1998). In the Barents Sea, the frequency of occurrence of shrimp in cod stomachs was negatively correlated with cod biomass in the period 1947-83, and positively correlated with shrimp biomass in the period 1980-85 (Ponomarenko and Yaragina, MS 1984; Berenboim et al., MS 1986). In the Gulf of Alaska, an increase in water temperature during the late-1970s triggered a decline in $P$. borealis and other shrimp and an increase in high trophic-level groundfish, including Pacific cod (Gadus macrocephalus) (Anderson et al., 1997; Anderson and Piatt, 1999). It was hypothesized that predation by groundfish may have accelerated the decline in shrimp populations.

Comprehensive assessments of shrimp and cod should include multispecies considerations (Jakobsson and Stefánsson, 1998). However, at present the biological interactions between these two species in the waters off southern Labrador and northeastern Newfoundland are poorly understood. This makes it difficult to address fundamental management questions, such as whether harvesting shrimp lightly to leave more food for cod might be effective in promoting recovery of the cod, and whether the shrimp stock and the fishery it supports must inevitably decline if the cod stock recovers.

The purpose of this paper is to consolidate information regarding changes in the biomass and distribution of shrimp and cod off southern Labrador and northeastern Newfoundland and to explore the hypothesis that the surge in shrimp biomass was a consequence of a reduction in predation pressure by cod. First, temporal trends in the indices of biomass of shrimp and cod will be examined to determine if the timing of the changes is consistent with the above hypothesis. Second, temporal changes in the quantity of shrimp consumed by the cod will be estimated and compared with changes in the biomass of the shrimp population, with emphasis on determining whether the increase in recruitment to the shrimp population was coincident with a reduction in removal of young shrimp by the cod. Finally, temporal changes in distribution of the shrimp fishery will be compared with changes in the distribution of the cod fishery, to determine if some of the expansion in the shrimp fishery occurred only after the cod fishery collapsed.

\section{Materials and Methods}

\section{Study area}

The stocks of interest are "northern" cod, which inhabits the shelf and adjacent coastal waters from southern Labrador to the northern Grand Bank (Div. $2 \mathrm{~J}+3 \mathrm{KL}$; Fig. 1), and northern shrimp, which is broadly distributed through this area in depths of approximately 200-500 m (Lilly et al., 1998). The 1994-96 shrimp Management Plan combined various shrimp fishing grounds in southern Div. 2J and $3 \mathrm{~K}$ into one Shrimp Fishing Area (SFA). This area called SFA6 encompasses those waters north of latitude $49^{\circ} 15^{\prime} \mathrm{N}$ and south of a line drawn from shore at latitude $53^{\circ} 45^{\prime} \mathrm{N}$, east to longitude $55^{\circ} 00^{\prime} \mathrm{W}$, thence north to latitude $54^{\circ} 45^{\prime} \mathrm{N}$, and thence east to the outer limit of the 200 mile economic zone (Fig. 1). Geographically, SFA6 encompasses the southern end of the Labrador Shelf and all but the southern end of the Northeast Newfoundland Shelf. Much of this shelf area is deep $(>200 \mathrm{~m})$ and there are several channels and deeps exceeding $300 \mathrm{~m}$. The Labrador Current flows southeastward along the shelf and keeps temperatures low (Smith et al., 1937). The cold intermediate layer of the current is deepest and coldest toward the coast, and temperatures below $0^{\circ} \mathrm{C}$ are found to depths of $200 \mathrm{~m}$ or more in many years (Petrie et al., 1988). Maximum bottom temperatures in the survey area are usually about $4{ }^{\circ} \mathrm{C}$ and occur near the shelf break.

\section{Indices of shrimp biomass}

The only indicator of shrimp biomass prior to 1995 is the trend in average catch rates experienced by commercial shrimp trawlers. Interpretation of these data is complicated by the complex history of fishing and management. A significant shrimp fishery in Hawke Channel and Div. 3K began in 1987 when about 1800 tons were caught (Table 1; Fig. 2). In previous years, only a few tons had been reported, primarily from Hawke Channel. Catches increased to more than 7800 tons in 1988 and ranged between 5500 and 8000 tons 


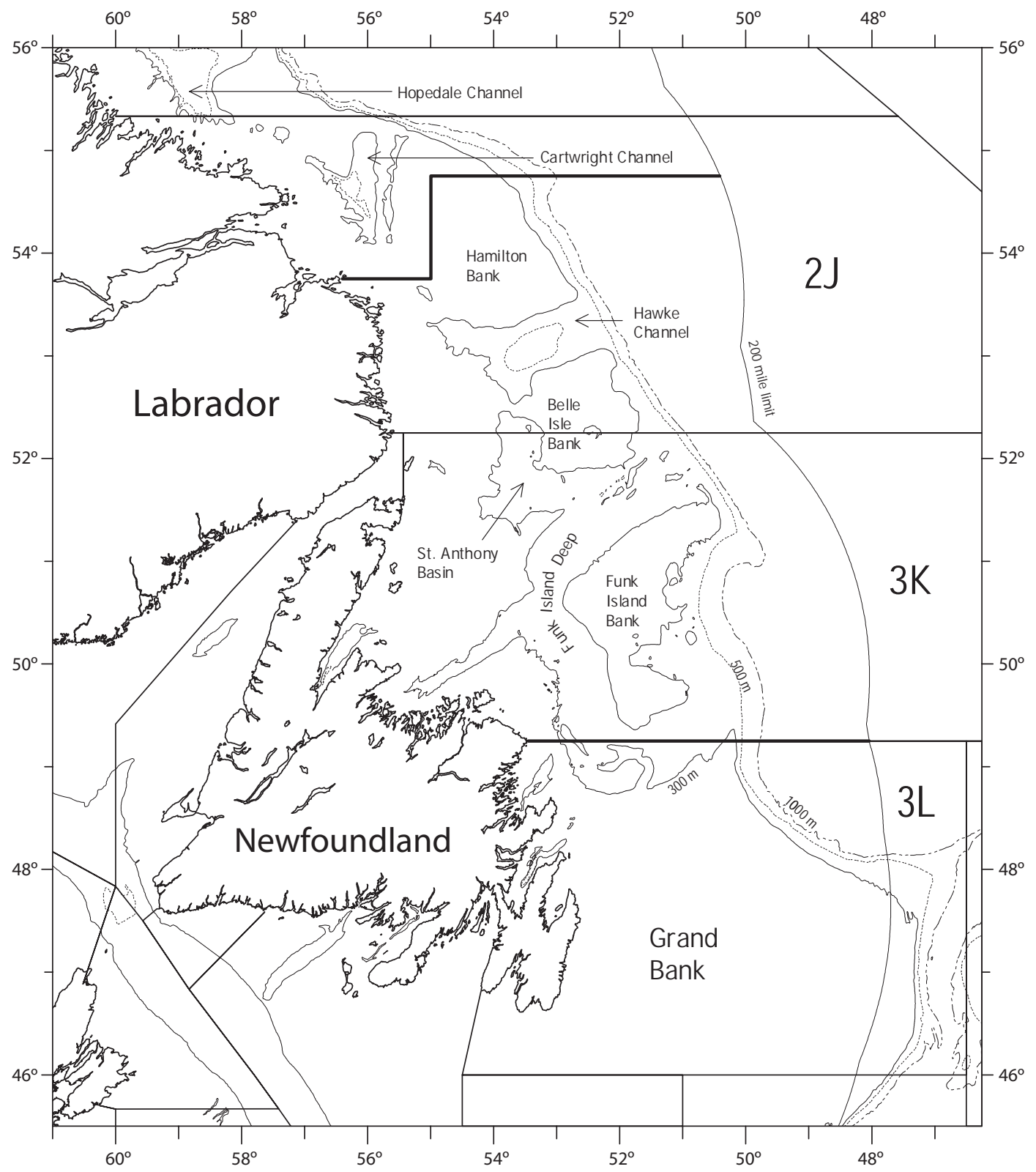

Fig. 1. Map of the study area, illustrating the area occupied by the northern cod stock (Div. 2J, 3K and $3 \mathrm{~L}$ ) and Shrimp Fishing Area 6 (Div. $3 \mathrm{~K}$ plus that part of Div. 2J south of the stepped line passing over Hamilton Bank). Also indicated are various geographic features mentioned in the text.

from 1989 to 1993. The annual TAC for the 1994-96 Management Plan was set at 11050 tons $(20 \%$ more than the 1993 TAC) for an area including shrimp fishing grounds in Hawke Channel, St. Anthony Basin, a depression on Belle Isle Bank, Funk Island Deep and three exploratory areas on the seaward slope of the shelf. The TAC was taken in each of those years. The assessment conducted in 1997 had the benefit of biomass estimates from the research trawl surveys in 1995 and 1996 (see below). Exploitation rates (ratio of nominal catch to survey biomass) were found to be low. Consequently, the TAC was raised to 23100 tons for 1997, the first year of the 1997-99 multi-year plan. Most of the increase was reserved for the development of an "inshore" component of smaller vessels $(<65$ feet). The catch in 1997 was estimated at 21000 tons. 
TABLE 1. Catches and stock size indices for shrimp in Shrimp Fishery Area 6 (Hawke Channel + Div. 3K) and stock size estimates and indices for cod in Div. 2J+3KL in 1977-98.

\begin{tabular}{|c|c|c|c|c|c|c|c|}
\hline \multirow[b]{3}{*}{ Year } & \multirow[b]{3}{*}{ TAC (tons) $)^{1}$} & \multicolumn{4}{|c|}{ Northern shrimp } & \multicolumn{2}{|c|}{ Atlantic cod } \\
\hline & & & CPUE (k & kg per hr) & & & \\
\hline & & Catch (tons) ${ }^{2}$ & $\begin{array}{c}\text { not } \\
\text { standardized }\end{array}$ & standardized $^{3}$ & $\begin{array}{c}\text { Survey } \\
\text { biomass (tons) }\end{array}$ & $\begin{array}{c}\text { Survey } \\
\text { biomass (tons) }\end{array}$ & $\begin{array}{c}\text { SPA } \\
\text { biomass (tons) }\end{array}$ \\
\hline 1977 & & 1 & 117 & & & & 511969 \\
\hline 1978 & 1300 & & & & & & 556959 \\
\hline 1979 & 2250 & 5 & 189 & & & & 684589 \\
\hline 1980 & 1350 & & & & & & 761742 \\
\hline 1981 & 1350 & 135 & 207 & & & 519000 & 884504 \\
\hline 1982 & 1350 & 1 & 151 & & & 442000 & 911530 \\
\hline 1983 & 1350 & & & & & 598000 & 959595 \\
\hline 1984 & 1350 & & & & & 551000 & 1073904 \\
\hline 1985 & 1350 & & & & & 387000 & 1060185 \\
\hline 1986 & 2050 & & & & & 952000 & 935319 \\
\hline 1987 & 3000 & 1845 & 333 & & & 450000 & 806360 \\
\hline 1988 & 3000 & 7849 & 536 & 824 & & 464000 & 695328 \\
\hline 1989 & 5600 & 6662 & 432 & 667 & & 506000 & 556235 \\
\hline 1990 & 5600 & 5598 & 507 & 839 & & 436000 & 383042 \\
\hline 1991 & 4301 & 5500 & 603 & 931 & & 207000 & 204909 \\
\hline 1992 & 7565 & 6609 & 774 & 1454 & & 62000 & 49370 \\
\hline 1993 & 9180 & 8035 & 891 & 1567 & & 13000 & 12932 \\
\hline 1994 & 11050 & 10978 & 1287 & 1566 & & 2500 & 4337 \\
\hline 1995 & 11050 & 10914 & 1836 & 2453 & 291243 & 12000 & 3822 \\
\hline 1996 & 11050 & 10923 & 2012 & 2789 & 517960 & 15900 & 5417 \\
\hline 1997 & 23100 & 21246 & 1966 & 2749 & 434548 & 16600 & 6669 \\
\hline 1998 & 46200 & 45676 & 1790 & 2264 & 475573 & 16600 & \\
\hline
\end{tabular}

1 Total allowable catches (TACs) are not consistently for SFA6 and the calendar year. See Parsons et al. (MS 1999).

2 Parsons et al. (MS 1999).

3 Catch-per-unit-effort (CPUE) was standardized by multiple regression in an attempt to account for variation due to month, area and ship. Only ships with participation over several years were included.

4 Biomass of shrimp in SFA6 as calculated by areal expansion of the stratified arithmetic mean catch-per-tow (Parsons et al., MS 1999).

5 Biomass of cod in Div. 2J+3KL as calculated by areal expansion of the stratified arithmetic mean catch-per-tow. The surveys in 1981-94 (Bishop et al., MS 1995) were conducted with an Engel 145 Hi-Rise otter trawl and those in 1995-98 (Lilly et al., MS 1999) were conducted with a Campelen 1800 shrimp trawl.

6 Population biomass of the Div. $2 \mathrm{~J}+3 \mathrm{KL}$ cod stock on January 1 as calculated by an illustrative sequential population analysis using the ADAPT formulation (Lilly et al., MS 1998).

Despite this large increase, exploitation remained low and the TAC was doubled for 1998. Catches again increased almost to the level of the TAC. The 1999 assessment concluded that the exploitation in 1998 was possibly less than $12 \%$.

Catch-per-unit-effort (CPUE) was calculated from data recorded in logbooks of trawlers fishing in SFA6 primarily during January to May (Parsons et al., MS 1999). These data were standardized by multiple linear regression to account for variability associated with individual vessel, month and subsets of the geographic area. Effort was low prior to 1987 and the associated average catch rates (Table 1; Fig 2) may not be reliable as an indicator of stock size. Nevertheless, it is thought that effort would have been greater if shrimp densities sufficient to support commercial fishing had been located. Effort increased substantially in 1987 and 1988. Unstandardized annual catch rates increased steadily from about $500 \mathrm{~kg}$ per hr during 1987-90 to 2 $000 \mathrm{~kg}$ per hr in 1996-97 and then declined to 1800 $\mathrm{kg}$ per hr in 1998. The trend in standardized catch rates was similar to that in unstandardized rates, but with a more pronounced decline in 1998 (Table 1; Fig. 2). 

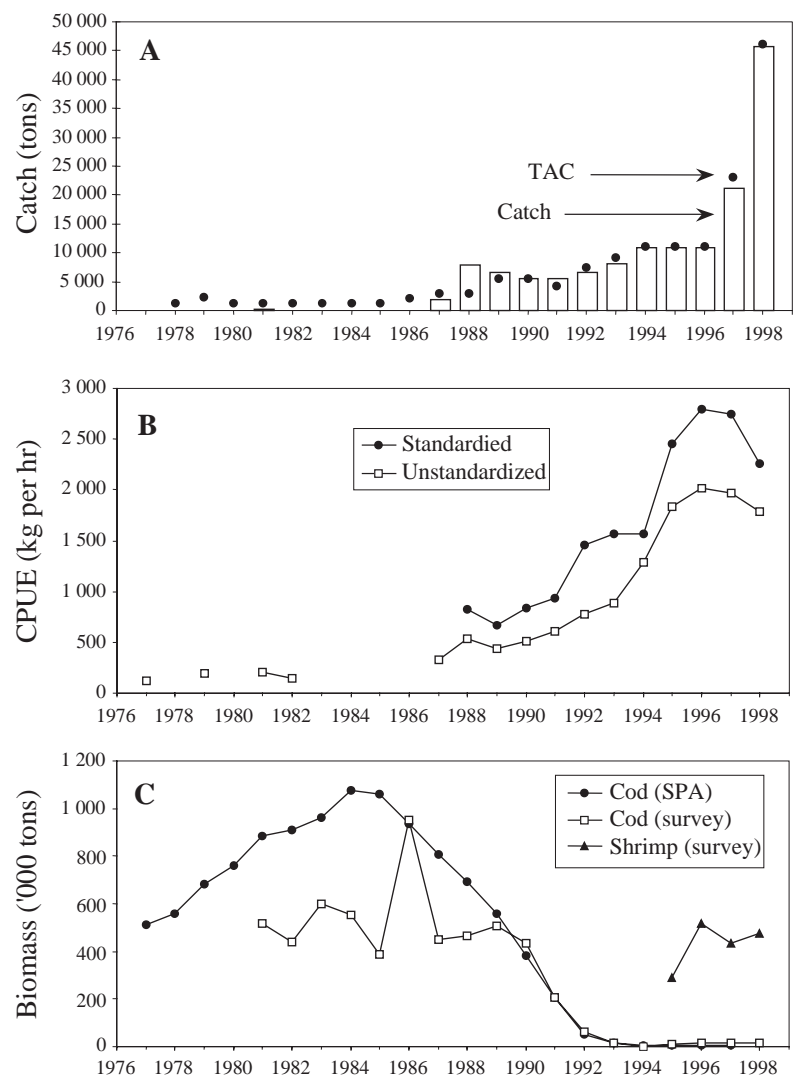

Fig. 2. Temporal trends in (A) TACs and catches of shrimp in SFA6, (B) catch-per-unit-effort in the trawler fishery in SFA6, both standardized and unstandardized and (C) biomass of shrimp in SFA6 as estimated from autumn trawl surveys and biomass of cod in Div. $2 \mathrm{~J}+3 \mathrm{KL}$ as estimated from sequential population analysis and the autumn bottom trawl survey index.

An index of shrimp biomass was also obtained from areal expansion of the stratified arithmetic mean catch per tow during random depth-stratified bottomtrawl surveys conducted during the autumn. These surveys started in 1978 in Div. 2J and 3K but not until 1981 in Div. 3L. Details regarding ships and gear employed, sampling dates and changes in survey pattern are provided by Lilly et al. (MS 1998). Stratum areas and locations are described by Doubleday (1981) and Bishop (MS 1994). Fishing in all Divisions and years was conducted on a $24-\mathrm{hr}$ basis. Near-bottom temperature was measured at the end of each fishing tow. The surveys prior to 1995 deployed an Engel 145 Hi-Lift trawl that caught very few shrimp and no effort was made to record shrimp by-catch. Starting in 1995 the Engel trawl was replaced with a Campelen 1800 shrimp trawl (McCallum and Walsh, 1997), facilitating the initiation of a new index for shrimp. The strata used in deriving the biomass index for shrimp in SFA6 are listed in Parsons et al. (MS 1999). Estimates for SFA6 were about $400000-500000$ tons in 1996-98 (Table 1; Fig. 2). The catchability of the Campelen trawl for shrimp under the circumstances of the autumn surveys is not known, but is expected to be less than 1 .

\section{Indices of cod biomass}

An index of the abundance and biomass of cod was derived from areal expansion of the stratified arithmetic mean catch-per-tow during random depthstratified bottom-trawl surveys conducted during the autumns of 1981-94 (see above). With the exception of an anomolously high value in 1986, the survey biomass index fluctuated without trend from 1981 to 1990 and then declined very rapidly (Table 1; Fig. 2).

The abundance of cod was also estimated from a reconstruction of the population based on commercial catch-at-age data "calibrated" with the autumn survey catch-at-age index using the ADAPT framework (Lilly et al., MS 1998). This sequential population analysis (SPA) suggested that the $3+$ biomass declined from about 3000000 tons in the early-1960s to less than 500000 tons in the mid-1970s, increased to about 1000000 tons in 1984-85 and then declined to less than 20000 tons by 1993 (Table 1; Fig. 2). The residuals between the model estimates and the research vessel index were large and in the same direction for a series of years in the late-1980s and early-1990s. One may therefore consider two possible trajectories for the stock biomass over that time period (Shelton and Lilly, 2000). If the reconstruction based on catches is close to what actually occurred (suggesting that the surveys were positively biased for the years noted above), then the cod population biomass declined steadily from the mid-1980s. However, if the pattern in the survey index more accurately reflects the trend in the cod population, then the stock biomass remained high until the late-1980s and then declined precipitously. In the latter scenario, there is a substantial quantity of fish unaccounted for in the early1990s (from unreported catch, which might include discards, or an increase in natural mortality). There is insufficient external evidence to reject either scenario.

\section{Cod stomach collection and examination}

Stomachs were collected from up to 3 randomly selected cod per 10-cm length-group per fishing tow in 1981-82 and 3 per 9-cm length-group in 1983-94. Stomachs were not collected from fish that showed signs of regurgitation, such as food in the mouth or a 
flaccid stomach. Stomachs were individually tagged, excised, and fixed and preserved in $4 \%$ formaldehyde solution in seawater prior to examination of their contents in the laboratory.

Examination involved separation of food items into taxonomic categories. Decapod crustacea were identified to species when possible. Pandalid shrimp that were not identified to species were recorded as unidentified Pandalidae. Some shrimp were recorded only as unidentified shrimp (Natantia). Items in each taxon were placed briefly on absorbent paper to remove excess liquid, and then counted and weighed to the nearest $0.1 \mathrm{~g}$.

\section{Consumption of shrimp by cod}

An estimate of the annual consumption of shrimp by cod within SFA6 was achieved in four steps: 1) calculation of the daily rate of consumption of shrimp and other prey by each of the individual cod sampled for stomach contents, 2) expansion of the daily consumption by individual cod to daily consumption by the cod population estimated from the trawl survey, 3 ) adjustment of the daily population consumption to account for the difference between the population estimate from the trawl survey and the population estimate from the SPA, and 4) extrapolation of daily population consumption to annual population consumption.

1. The daily rate of consumption of shrimp and other prey by each sampled cod was estimated from stomach content data using the steady state consumption model of dos Santos and Jobling (1995). The "restricted form" of this model is

$$
\hat{C}_{i}=\frac{24 * \ln 2 * e^{\gamma T} * B^{\delta} * S_{i}}{\alpha_{i} *\left(\sum_{i=1}^{n} S_{i}\right)^{\beta}}
$$

where $\hat{C}_{i}$ is the estimated consumption (g per day) of prey $i, S_{i}$ is the weight (g) of prey $i$ in the stomach at the time of sampling, $B$ is the size $(\mathrm{cm})$ of the predator, $T$ is temperature, $\gamma=0.13, \beta=$ $0.48, \delta=0.46$, and $\alpha$ values are prey-specific, including $\alpha=117$ for shrimp (see equation 6 and Table 3 of dos Santos and Jobling, 1995).

Near-bottom temperature measurements were not available for some fishing stations (mean $=1.8 \%$ of the stations fished each year, range $=0-5 \%$ ). In such instances, near-bottom temperature was estimated from temperature data recorded at other fishing stations in SFA6 within the same year using a predictive regression of temperature on depth, depth squared and longitude. The model structure reflects in a simplified way the structure of the temperature field in the autumn. Temperatures declined from the surface to a minimum at about $200 \mathrm{~m}$ and increased again to reach a maximum at about $500 \mathrm{~m}$. The core of the cold intermediate layer (CIL) is deeper toward the coast, which is to the west. The model did not capture the warming of water at depths above the core of the CIL, but few tows were made in this area. The $5^{\text {th }}$ and $95^{\text {th }}$ percentiles of the residuals from the regression were calculated for each year. These averaged $-1.1^{\circ} \mathrm{C}$ and $1.1^{\circ} \mathrm{C}$, respectively, over the 14 years of the study.

The application of the consumption model to the stomach contents of each sampled cod provided an estimate of the rate (g per day) at which shrimp and other prey were passing through the cod stomach. The next step was to calculate the average rate of consumption by the cod population and to multiply that by population size.

2. Warren et al. (MS 1994) presented a method for estimating the population mean stomach content weight of cod from a stratified-random trawl survey and length-stratified stomach sampling. Their method was adopted here, with the rate of consumption of prey replacing the stomach content weight. Briefly, for each 9-cm length-group of cod, a mean feeding rate by the cod within each stratum was calculated as the mean of tow means, where each tow mean was weighted by the catch (number) in that tow. Then, for each stratum and cod lengthgroup, the feeding rate on shrimp was adjusted upward to account for unidentified Pandalidae and unidentified shrimp. Finally, for each cod lengthgroup, the mean feeding rate for SFA6 was calculated as the mean of stratum means, where each stratum mean was weighted by the population number in that stratum. The population number in each stratum was estimated by areal expansion of the arithmetic mean catch-per-tow. Note that for a variety of reasons there were some instances where cod were caught within a specific stratum and length-group but there were no observations of stomach contents. The percentage of the estimated population not represented in the calculations of stratified mean feeding rate was very low (mean $=$ $0.4 \%$, range $=0.01-1.09 \%$ ) in 1982-94 but higher $(9.3 \%)$ in 1981 when stomachs from 25 fishing tows in northern Div. $3 \mathrm{~K}$ were lost. It is assumed 
that the stratified mean feeding rate could also be applied to those fish not represented in the calculations. Note as well that the variance of the estimate of the quantity of shrimp consumed by the cod population sampled by the trawl in each year is not presented, but it would be large (Warren et al., MS 1994).

The daily consumption of shrimp and other prey by the cod population was calculated by multiplying the stratified mean feeding rate within each cod length-group by the estimate of cod population abundance in that length-group, and then summing over length-groups.

3. The estimate of population size from the survey is actually an index, and must be adjusted to make it equivalent to the population size estimated from the SPA. This involves both an adjustment for catchability (a time-invariant age-specific catchability is assumed within the SPA) and an adjustment for annual deviation between the survey index and the SPA estimate. For simplicity, a yearspecific population adjustment factor was calculated as the population biomass from the SPA on 1 January in year $t+1$ divided by the population biomass estimated from the survey in Div. $2 \mathrm{~J}, 3 \mathrm{~K}$ and $3 \mathrm{~L}$ combined in year $t$. The daily consumption of shrimp by the cod population estimated from the trawl survey in SFA6 alone (step 2) was then multiplied by the appropriate year-specific population adjustment factor.

4. Extrapolation from a daily rate of consumption in the autumn to an estimate of annual consumption requires information on the seasonal pattern of predation by cod on shrimp. However, there is no time series of stomach content data at other seasons and very little is known about seasonal variation in the degree of spatial overlap between the species. Most cod spend the winter aggregated near the shelf break. In the late spring they move onto the shelf, and many cross the shelf to feeding areas in shallow coastal waters where they remain until the autumn. The annual monitoring of stomach content data occurs during the autumn when the cod are migrating back across the shelf toward the shelf break. Opportunistic stomach sampling reveals that feeding intensity on shrimp may be very low when the cod are aggregated near the shelf break in winter (Lilly et al., MS 1984), and there is no predation on shrimp by those cod that are in shallow water in summer (Lilly and Botta, MS 1984). However, there are some cod on the shrimp grounds from winter through summer and some predation on shrimp will occur, especially in summer. For the present speculation, it was assumed that cod might prey on shrimp at the calculated daily rate for 5 to 9 months in a year.

\section{Commercial fishing areas}

Fishery observers collected geo-referenced information on catch and effort from individual fishing sets in the trawler fisheries for groundfish and shrimp in January to April 1986-93 in a manner specified by Kulka and Firth (1987). The catch rate (tons per hr) of cod in each set was standardized using a multiplicative model (Gavaris, 1980) to adjust for variation in vessel class and country. It was not necessary to standardize the shrimp catch rates because vessel class and country did not vary. Potential mapping in SPANS (Anon, MS 1997; Kulka, MS 1998) was used to convert point data (catch rate and starting latitude and longitude for each set) to surface maps depicting the distribution of the fishery and the distribution of cod and shrimp within the area fished.

\section{Results}

\section{Consumption of shrimp by cod}

The mean per capita rate of feeding (g per day) on shrimp by cod in SFA6 at the time of each bottomtrawl survey was variable during the 1980 s, with the lowest values tending to occur in the mid-1980s and in 1990 (Table 2; Fig. 3). Per capita rate of feeding on shrimp tended to increase during the early-1990s.

The daily consumption of shrimp by the cod population in SFA6 was obtained by multiplying the per capita feeding rate by the population size within each length-group, and then summing over lengthgroups. For example, in 1987 (Table 3) the per capita feeding rate on shrimp was highest for cod in the 63$71 \mathrm{~cm}$ length-group, but population consumption of shrimp was highest in the $45-53 \mathrm{~cm}$ group. The contribution of shrimp to the total food consumption of cod in SFA6 peaked at $7.4 \%$ in the $45-53 \mathrm{~cm}$ lengthgroup and averaged $5.9 \%$ in the population. The rate of consumption of shrimp by cod in SFA6 in autumn 1987 was calculated to be 57 tons per day. Similar calculations for other years in the period 1981-94 produced daily consumption rates as high as 111 tons per day in 1983 and as low as 1 ton per day in 1994 (Table 4; Fig. 4).

The above calculations are for the cod population estimated from catches within SFA6 during each 
J. Northw. Atl. Fish. Sci., Vol. 27, 2000

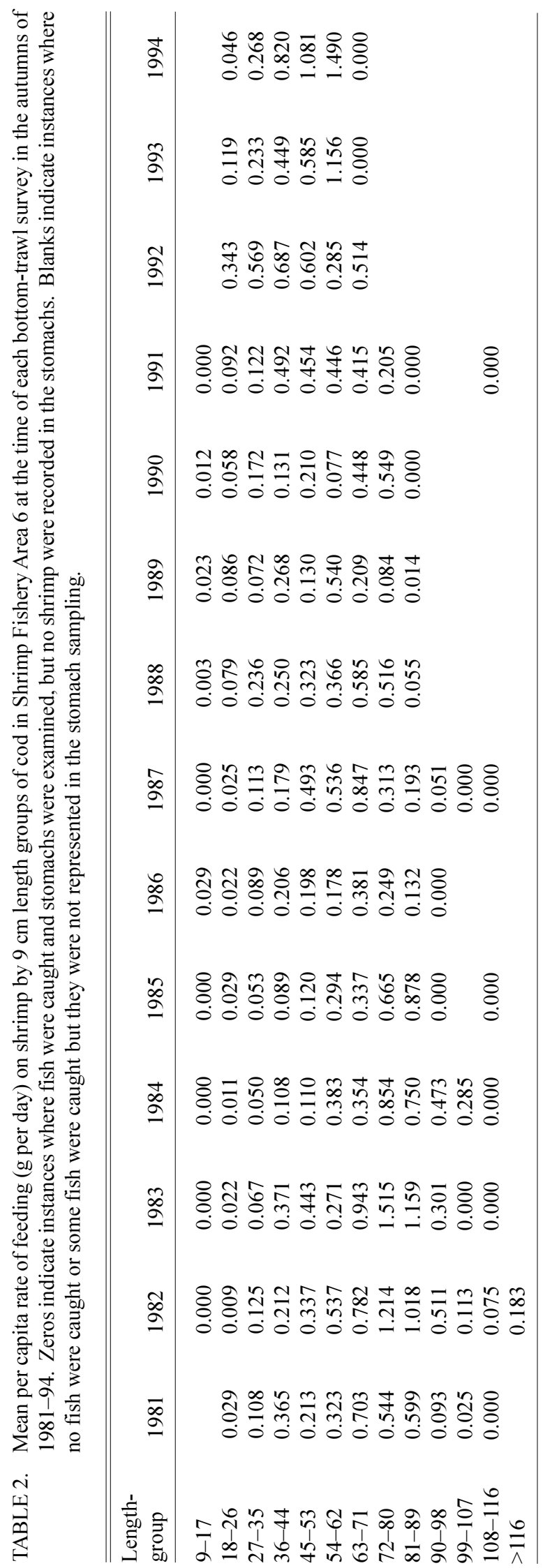


bottom-trawl survey. To account for the difference between the population estimate from the survey and the population estimate from the SPA, each consumption estimate was multiplied by a year-specific adjustment factor. This adjustment factor varied from 0.2 in 1992 to 2.4 in 1985 (Table 4). The daily consumption based on this adjusted estimate of population size ranged from 200 tons per day in 1983 to 1 ton per day in 1993 (Table 4; Fig. 4).

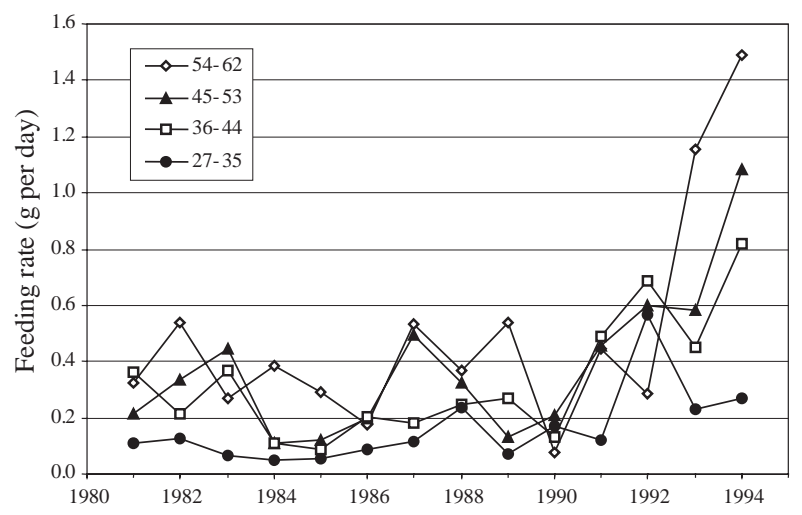

Fig. 3. Mean per capita rate of feeding ( $g$ per day) on shrimp by $9 \mathrm{~cm}$ length groups of cod in Shrimp Fishery Area 6 at the time of each bottom-trawl survey in the autumns of 1981-94.
The daily consumption of shrimp by cod is calculated from data collected during a single survey of SFA6. The extent to which this consumption rate is appropriate to other times during the year is not known. For the present speculation, it is assumed that cod might prey on shrimp at the calculated daily rate for as few as 5 months in a year and as many as 9 months. The highest consumption calculated in this manner was 55000 tons in 1983 (Table 4; Fig. 5). For most years prior to 1990 , the consumption tended to lie in the range 10 000-25 000 tons. The fishery catch was exceeding cod removals by the early-1990s and by 1998 the fishery was removing about as much shrimp as had been consumed by cod in the year of highest estimated consumption (1983).

\section{Geographic fishing patterns}

Cod historically aggregated in winter on the outer shelf and upper slope off southern Labrador and northeastern Newfoundland. Acoustic surveys during the winters of 1987-92 revealed that in 1987-89 the cod were aggregated primarily in depths of 300-500 $\mathrm{m}$, but that in 1990-92 they moved deeper and became more aggregated toward the southern part of Div. $3 \mathrm{~K}$ and northern Div. 3L (Baird et al., MS 1992). Similar patterns were seen in the winter cod fishery (Kulka et al., 1995). During most of the 1980s the fishery was prosecuted all along the eastern edge of the shelf, with

TABLE 3. Details of the calculation of consumption of shrimp and all prey combined by cod in Shrimp Fishery Area 6 in 1987.

\begin{tabular}{|c|c|c|c|c|c|}
\hline $\begin{array}{l}\text { Length- } \\
\text { group }\end{array}$ & $\begin{array}{l}\text { Feeding rate } \\
\text { (g per day) }\end{array}$ & $\begin{array}{l}\text { Population }^{2} \\
\text { number } \\
\text { (millions) }\end{array}$ & $\begin{array}{l}\text { Population con } \\
\text { of shrimp } \\
\text { (tons per day) }\end{array}$ & $\begin{array}{l}\text { sumption } \\
\text { of all food } \\
\text { (tons per day) }\end{array}$ & $\begin{array}{c}\text { Contribution } \\
\text { by shrimp } \\
(\%)\end{array}$ \\
\hline $9-17$ & 0.000 & 0.093 & 0.000 & 0.086 & 0.0 \\
\hline $18-26$ & 0.025 & 1.231 & 0.030 & 1.498 & 2.0 \\
\hline $27-35$ & 0.113 & 3.835 & 0.433 & 8.608 & 5.0 \\
\hline $36-44$ & 0.179 & 17.227 & 3.092 & 81.492 & 3.8 \\
\hline $45-53$ & 0.493 & 52.935 & 26.087 & 351.972 & 7.4 \\
\hline $54-62$ & 0.536 & 35.743 & 19.151 & 322.072 & 5.9 \\
\hline $63-71$ & 0.847 & 8.446 & 7.154 & 104.167 & 6.9 \\
\hline $72-80$ & 0.313 & 3.109 & 0.973 & 58.830 & 1.7 \\
\hline $81-89$ & 0.193 & 0.731 & 0.141 & 19.541 & 0.7 \\
\hline $90-98$ & 0.051 & 0.274 & 0.014 & 13.593 & 0.1 \\
\hline $99-107$ & 0.000 & 0.029 & 0.000 & 0.648 & 0.0 \\
\hline $108-116$ & 0.000 & 0.015 & 0.000 & 0.516 & 0.0 \\
\hline \multicolumn{6}{|l|}{$>116$} \\
\hline Total & & 123.67 & 57.075 & 963.023 & 5.9 \\
\hline
\end{tabular}

1 Stratified arithmetic mean feeding rate by cod on shrimp (from Table 2).

2 Population of cod in Shrimp Fishery Area 6 calculated by areal expansion of the stratified arithmetic mean catch per tow. 
TABLE 4. Calculation of the quantity of shrimp consumed by the cod in SFA6. For each year the daily consumption by the cod population estimated from the trawl survey is adjusted to daily consumption by the population estimated from sequential population analysis (SPA). This daily consumption is extrapolated to annual consumption under scenarios that assume that the daily consumption estimated in the autumn is applicable for 5, 7 or 9 months.

\begin{tabular}{|c|c|c|c|c|c|c|}
\hline & \multirow{2}{*}{$\begin{array}{l}\text { Consumption (tons per day) } \\
\text { by cod population } \\
\text { estimated from survey }\end{array}$} & \multirow{2}{*}{$\begin{array}{c}\text { Population }{ }^{1} \\
\text { adjustment } \\
\text { (SPA/survey) }\end{array}$} & \multirow{2}{*}{$\begin{array}{l}\text { Consumption (tons per day) } \\
\text { by cod population } \\
\text { adjusted for catchability }\end{array}$} & \multicolumn{3}{|c|}{$\begin{array}{l}\text { Annual consumption (tons) } \\
\text { for feeding period of: }\end{array}$} \\
\hline & & & & 5 months & 7 months & 9 months \\
\hline 1981 & 44.5 & 1.76 & 78.2 & 11889 & 16660 & 21431 \\
\hline 1982 & 65.8 & 2.17 & 142.8 & 21711 & 30424 & 39137 \\
\hline 1983 & 111.3 & 1.80 & 199.8 & 30373 & 42562 & 54751 \\
\hline 1984 & 42.0 & 1.92 & 80.8 & 12283 & 17212 & 22141 \\
\hline 1985 & 22.3 & 2.42 & 53.8 & 8178 & 11460 & 14742 \\
\hline 1986 & 72.1 & 0.85 & 61.1 & 9281 & 13006 & 16731 \\
\hline 1987 & 57.1 & 1.55 & 88.2 & 13405 & 18785 & 24164 \\
\hline 1988 & 39.7 & 1.20 & 47.6 & 7230 & 10132 & 13033 \\
\hline 1989 & 79.4 & 0.76 & 60.1 & 9138 & 12806 & 16473 \\
\hline 1990 & 33.6 & 0.47 & 15.8 & 2401 & 3364 & 4328 \\
\hline 1991 & 77.4 & 0.24 & 18.4 & 2804 & 3929 & 5055 \\
\hline 1992 & 8.6 & 0.21 & 1.8 & 272 & 381 & 490 \\
\hline 1993 & 2.3 & 0.33 & 0.8 & 116 & 163 & 210 \\
\hline 1994 & 1.4 & 1.53 & 2.1 & 316 & 443 & 570 \\
\hline
\end{tabular}

1 The population adjustment for catchability in year $t$ was calculated as the SPA biomass on 1 January in year $t+1$ divided by the survey biomass in year $t$.

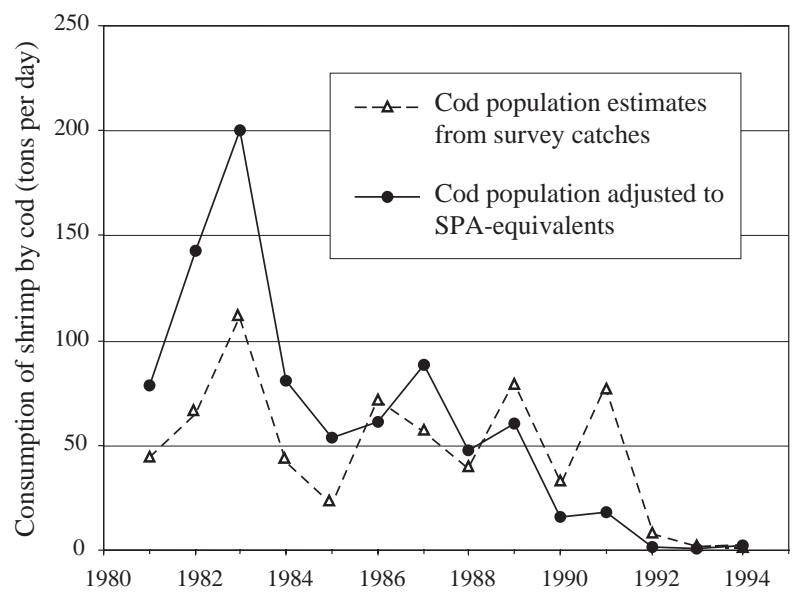

Fig. 4. Daily consumption of shrimp by the cod population in Shrimp Fishery Area 6 in the autumns of 1981-94. For each year consumption is shown for the cod population estimated from the trawl survey and for that population after adjustment to become equivalent to the estimate from sequential population analysis (SPA).

areas of highest catch rates and most intensive fishing southeast of Hamilton Bank, between Belle Isle Bank and Funk Island Bank, and south of Funk Island Bank (Fig. 6). By 1990 most of the fishing and highest catch

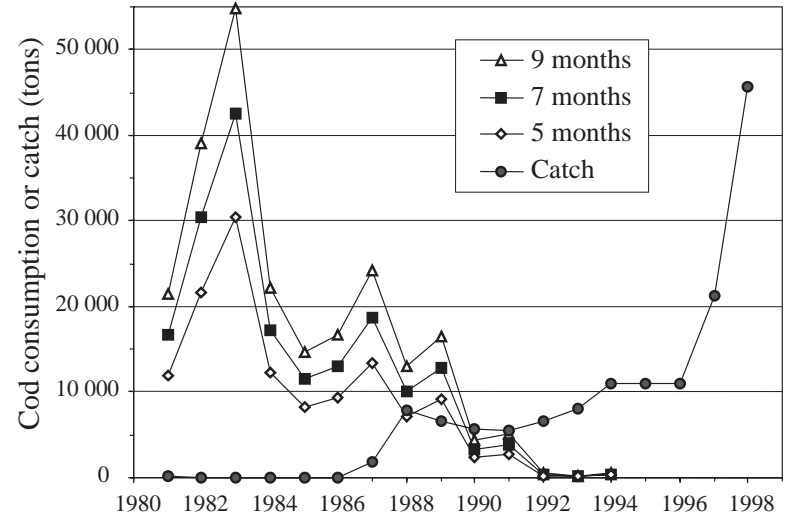

Fig. 5. Annual consumption of shrimp by the cod population estimated to be within Shrimp Fishing Area 6 (SFA6), after adjustment to SPAequivalents, under assumptions that the daily feeding rate calculated from sampling during the annual survey is applicable for 5, 7 or 9 months. Also shown is the annual catch of shrimp from SFA6.

rates were east of Funk Island Bank and by 1991 they were mainly to the southeast of the bank. There was only a small amount of fishing in 1992, mainly in northern Div. 3L. The offshore fishery has been closed since summer 1992. 
An experimental fishery for northern shrimp started in Hawke Channel in the mid-1970s, but the fishery developed farther north in the Cartwright and Hopedale Channels (Fig. 1) where catch rates were higher. Fishing increased in Hawke Channel during the winter of 1987 (Fig. 6). Large vessel operators, licensed to fish only for shrimp, were willing to test a winter fishery as an alternative to remaining idle for several months of the year. Catch rates were high enough to sustain effort. Some activity was also reported in the adjacent St. Anthony Basin to the south. In 1988, effort increased in both these areas and expanded to include Funk Island Deep and a depression on Belle Isle Bank. In the absence of a clear picture of stock distribution, separate TACs were enforced for each of the four fishing areas up to 1993. In 1992 and 1993, exploratory fishing zones seaward along the shelf edge were established with separate quotas. These areas also proved to be productive. Fishing activity in 1993 and subsequent years was largely along the shelf edge where catch rates were high and sea ice was less of a hindrance to fishing than in shelf areas to the west.

The shrimp fishery on the edge of the bank did not start until 1992, by which time there were very few cod and almost no cod fishing activity north of southeastern Funk Island Bank. The new shrimp grounds near the shelf edge in SFA6 are in the same area and at approximately the same depth range as the former cod fishing grounds and are being fished at the same time of year (mainly January to April).

\section{Discussion}

Biological changes in the ecosystem of the Northeast Newfoundland Shelf during the late-1980s and 1990s included a collapse in cod biomass and a substantial increase in shrimp biomass. In the absence of several periods of increase and decrease in the documented time series of both stocks, it is not possible to use correlation analysis (e.g. Ponomarenko and Yaragina, MS 1984; Stefánsson et al., 1998) or time series analysis to gain insight into the relationship between the two species. Instead, the possibility of an interaction was investigated by exploring whether the timing and magnitude of changes in cod biomass and predation by cod on shrimp were consistent with the hypothesis that the increase in shrimp biomass in SFA6 was a consequence of a reduction in predation pressure from cod. This exercise has illustrated some of the challenges associated with testing for predator-prey interactions using data derived from resource monitoring. There is uncertainty in the biomass trends of both species and in the estimates of consumption that link the two.

The trend in shrimp biomass from the early-1980s to the mid-1990s remains uncertain because of the absence of research surveys covering the whole area prior to 1995, the small amount of fishing effort prior to 1987, and the manner in which the fishery expanded from Hawke Channel to additional areas during the late-1980s and early-1990s. Nevertheless, it is thought that biomass was low prior to the mid-1980s because CPUE was low and it is suspected that effort would have been greater if shrimp densities sufficient to support commercial fishing had been located. An increase in shrimp biomass during the 1980s is also inferred from research trawl surveys in Hawke Channel, where biomass estimates increased from an average of about 3000 tons in $1979-81$ to about 7800 tons in 1988-90 (Parsons and Veitch, MS 1991). The change in distribution of fishing effort by large trawlers, from the central part of the shelf to the shelf break area, is understood to be a consequence of finding shrimp concentrations that could be fished with less interference from ice rather than a decline in catch rates on the central shelf. Research surveys during the autumns of 1995-99 have demonstrated high shrimp densities throughout the deep water of the shelf.

The trend in cod biomass is thought to have been well represented by the SPA estimates until the mid1980 s. Uncertainty arises because of inability to reconcile reported catches and the research vessel index during the late-1980s and early-1990s.

The estimates of consumption of shrimp by cod remain uncertain for many reasons. First, it is not known if the consumption model used to estimate feeding rates is appropriate for cod in the study area, particularly since many of the cod were caught in water temperatures below those employed in the laboratory studies from which the consumption model was derived. Second, there is considerable year-to-year variability in estimates of daily consumption during the autumn. This might be caused by annual variability in many factors, including the temperature of the water, the quantity of cod found within SFA6 at the time of the survey, the biomass of shrimp within SFA6, the spatial overlap between cod and shrimp within SFA6 at the time of the survey, and the abundance and availability of alternate prey, especially capelin. Exploration of the various factors that may have affected the estimates of daily consumption is beyond the scope of the present paper. Third, the temporal 

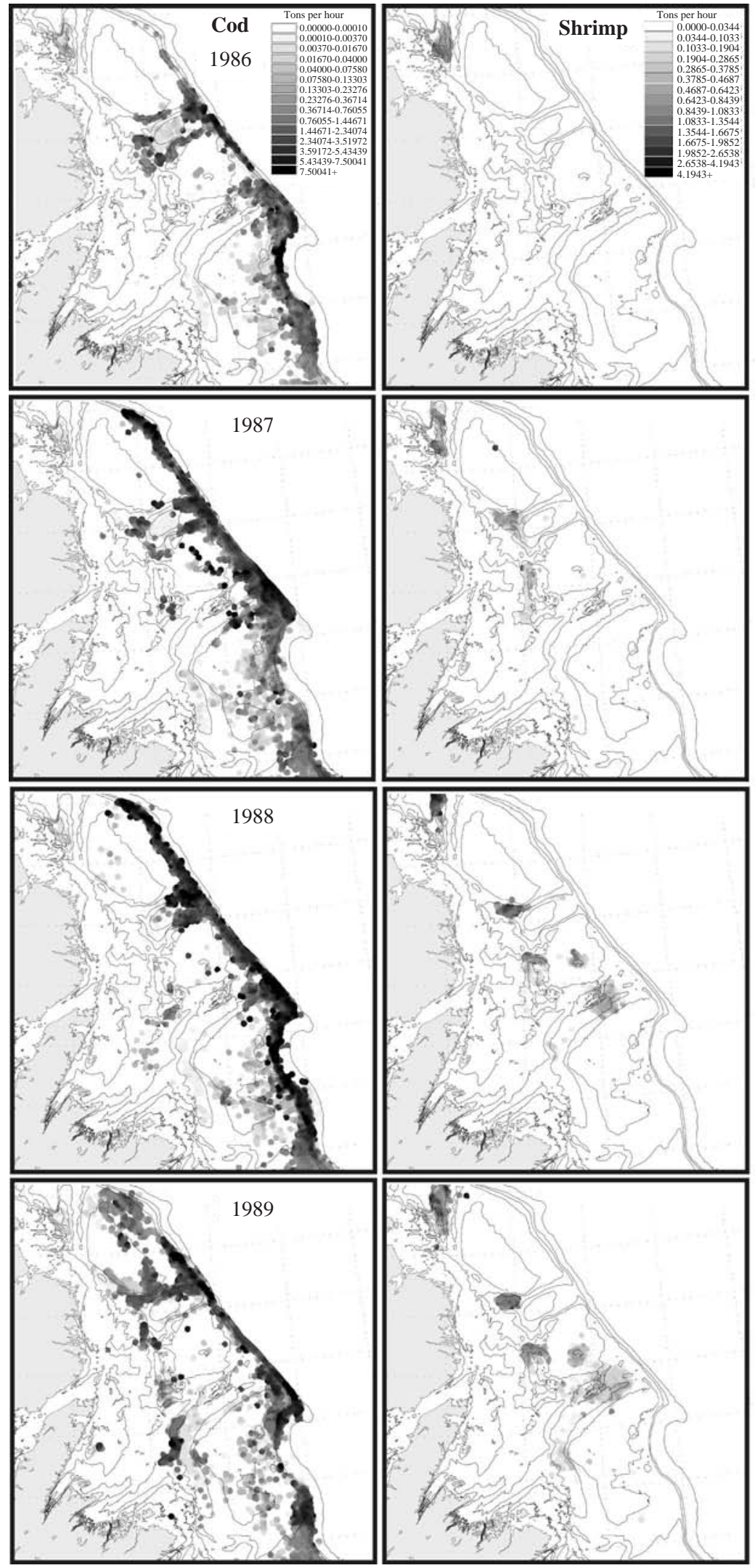

Fig. 6. Changes in the distribution of the commercial trawler fisheries for cod and shrimp during 1986 to 1993. The shading indicates average catch-per-unit-effort on small spatial scales from fisheries predominantly in January to April. 


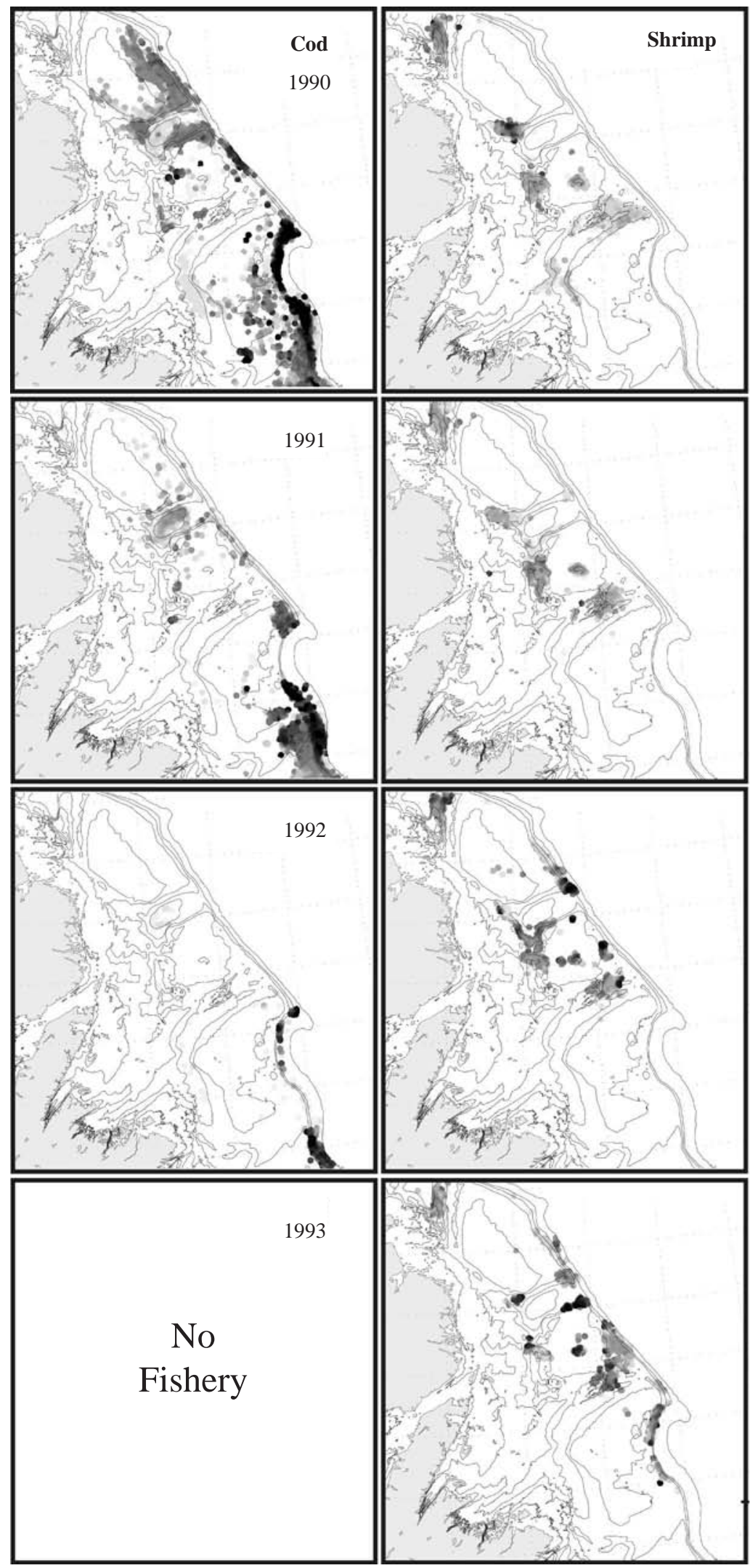

Fig. 6. (Continued). Changes in the distribution of the commercial trawler fisheries for cod and shrimp during 1986 to 1993. The shading indicates average catch-per-unit-effort on small spatial scales from fisheries predominantly in January to April. 
pattern in daily consumption by the cod population during the autumn varies with the source of information regarding the size of the cod stock. If the SPA well represents the trend in biomass, then there was a downward trend in consumption of shrimp starting in the early-1980s. If, however, the surveys more accurately reflect the trend in stock status, then consumption probably remained high from the mid1980 s to the early-1990s and then declined precipitously. Fourth, there is a paucity of information on the consumption of shrimp by cod at times other than the autumn. The present estimates of annual consumption are guesses based on extrapolation from daily estimates derived from sampling on one day only at each point in space.

Given the various uncertainties noted above, what can be concluded regarding the role of cod in the rise of shrimp? It is instructive to consider two time periods; an initial increase in the 1980s and a later and larger increase in the 1990s. The increase in shrimp catch that began in 1987 is presumed to reflect an increase in the density and probably the biomass of commercial size shrimp at about that time. However, in the absence of a survey series that can provide an index of the abundance of shrimp at length (and age), it is not possible to determine whether the increase in large shrimp was due to increased settlement of 0-group shrimp, increased survival after settlement or a combination of the two. The lack of a shrimp survey also precludes determining the timing of such changes. However, because the commercial fishery tends to concentrate on large shrimp of ages 5 and older (Parsons et al., 1986), the change is presumed to have started no later than some time in the early-1980s. Cod feed on the full size spectrum of shrimp, but take mainly juveniles and males (Parsons et al., 1986; Lilly et al., 1998). Thus, if the initial increase in shrimp biomass resulted from a decrease in predation by cod, then the decrease in predation should have started in the early$1980 \mathrm{~s}$. This is not consistent with the trend in cod biomass, which, according to the SPA, increased from a low in the mid-1970s to a high in the mid-1980s. If the survey is a reliable indicator of trends after the mid1980 s, then the cod biomass increased from the mid1970 s to the mid-1980s and then remained relatively constant until a precipitous decline in the early-1990s.

The role of cod in the increase of shrimp should be more apparent from the consumption estimates. However, the large changes in the estimates of per capita consumption between 1981 and 1985 illustrate the variability that can be found in such data. As noted above, there are many factors that could affect such estimates. Until such time as the year-to-year variability in these estimates is better understood, it is prudent to assume that the trend in cod biomass may be a more reliable indicator of the trend in consumption of shrimp by cod.

Although the temporal pattern in consumption of shrimp by cod during the 1980 s remains uncertain, it is clear that there was very little consumption of shrimp after 1991. This reduction in consumption must certainly have contributed to the increase in shrimp biomass that has been inferred from the large increase in CPUE in the shrimp fishery through the 1990s.

There remains the question of whether the consumption of shrimp by cod in the 1980 s was sufficient to prevent the shrimp population from increasing. Although one estimate of annual consumption approached 55000 tons, most estimates were below 20000 tons. Such removals seem small compared with a catch of 45000 tons in 1998 and a trawlable biomass (with no adjustment for catchability) between 400000 tons and 500000 tons in 1996-98. Note, however, that the reduction in removals by all predators combined may be greater than that by cod alone. Declines in biomass have been seen in other demersal fish (Atkinson, 1994; Gomes et al., 1995) and some of these, including Greenland halibut, thorny skate and roughhead grenadier, are known to prey on shrimp (Bowering and Lilly, 1992; Parsons et al., 1998). On the other hand, the population of harp seals, another predator on shrimp (Hammill and Stenson, MS 1997), has been increasing since the 1970s (Stenson et al., MS 1999). Further exploration of the role of predation in the dynamics of shrimp in SFA6 may benefit from a simulation of the survival of shrimp cohorts under various scenarios of removals at age by cod and an investigation of the changes in consumption by other predators.

The increase in shrimp biomass appears to have involved not only an increase in density, as reflected in the increase in CPUE, but an increase in area occupied. The new winter/spring fishing grounds near the edge of the shelf overlap to a large degree the former cod fishing grounds. It is not entirely certain that shrimp were not abundant in this area prior to the cod collapse, for the cod fishery was conducted by a different fleet deploying gears that would not have caught shrimp. Nevertheless, there is indirect and circumstantial evidence in support of this contention. First, Sandeman (MS 1978) reported a conversation 
in which he was told that "attempts to fish for shrimp along the outer edge of the Labrador shelf did not indicate any significant concentrations when this area was surveyed by a USSR vessel undertaking research on shrimp in 1975". Second, reports of the stomach contents of cod caught in this area in winter in the late1970s and early-1980s indicate that there was very little if any predation on shrimp (Lilly et al., MS 1984; Lilly, 1987). Third, it is unlikely that aggregations of shrimp would occupy the same area as large aggregations of cod. For example, while repeatedly fishing a single station in St. Anthony Basin in July 1991, Parsons et al. (MS 1991) found that catches of shrimp declined dramatically after a large concentration of cod moved into the study area.

\section{Acknowledgements}

The analyses in this paper draw upon the efforts of many people, including the scientific staff who participated in the research surveys, observers who recorded the commercial catch rates, and the companies and people who examined the cod stomach contents. G. Cossitt provided the geographic map. Much of the approach to estimating the consumption of cod, as adopted in this paper, was developed in collaboration with H. Hop. Comments by two anonymous reviewers were very helpful.

\section{References}

ALBERS, W. D., and P. J. ANDERSON. 1985. Diet of the Pacific cod, Gadus macrocephalus, and predation on the northern pink shrimp, Pandalus borealis, in Pavlof Bay, Alaska. Fish. Bull. U.S., 83: 601-610.

ANDERSON, P. J., J. E. BLACKBURN, and B. A. JOHNSON. 1997. Declines of forage species in the Gulf of Alaska, 1972-1995, as an indicator of regime shift. In: Forage fishes in marine ecosystems. Proceedings of the international symposium on the role of forage fishes in marine ecosystems. Alaska Sea Grant College Program Rep., 97-01. University of Alaska Fairbanks, p. 531-543.

ANDERSON, P. J., and J. F. PIATT. 1999. Community reorganization in the Gulf of Alaska following ocean climate regime shift. Mar. Ecol. Prog. Ser., 189: 117-123.

ANON. MS 1997. SPANS. Vers. 7. Prospector Reference Manual. TYDAC Research Inc.

ATKINSON, D. B. 1994. Some observations on the biomass and abundance of fish captured during stratified-random bottom trawl surveys in NAFO Divisions $2 \mathrm{~J}$ and $3 \mathrm{KL}$, autumn 1981-1991. NAFO Sci. Coun. Studies, 21: 4366.

BAIRD, J. W., C. R. STEVENS, and E. F. MURPHY. MS 1992. A review of hydroacoustic surveys conducted during winter for 2J3KL cod, 1987-1992. Can. Atl. Fish. Sci. Adv. Comm. Res. Doc, No. 107, 14 p.

BERENBOIM, B.I., I.Ya. PONOMARENKO, and N.A. YARAGINA. MS 1986. On "predator-prey" relationship between cod and shrimp Pandalus borealis in the Barents sea. ICES C. M. Doc., No. G:21.

BISHOP, C. A. MS 1994. Revisions and additions to stratification schemes used during research vessel surveys in NAFO Subareas 2 and 3. NAFO SCR Doc., No. 43, Serial No. N2413, 23 p.

BISHOP, C. A., D. E. STANSBURY, and E. F. MURPHY. MS 1995. An update of the stock status of Div. 2J3KL cod. DFO Atl. Fish. Res. Doc., No. 34, 38. p.

BOWERING, W. R., and G. R. LILLY. 1992. Greenland halibut (Reinhardtius hippoglossoides) off southern Labrador and northeastern Newfoundland (Northwest Atlantic) feed primarily on capelin (Mallotus villosus). Neth. J. Sea Res., 29: 211-222.

BOWERING, W. R., D. G. PARSONS, and G. R. LILLY. MS 1983. Predation on shrimp (Pandalus borealis) by Greenland halibut (Reinhardtius hippoglossoides) and Atlantic cod (Gadus morhua) off coastal Labrador (Div. $2 \mathrm{H}$ and 2J). NAFO SCR Doc., No. 88, Serial No. N754, $26 \mathrm{p}$.

CARLSSON, D. M., and E. SMIDT. 1978. Shrimp, Pandalus borealis Kroyer, stocks off Greenland: biology, exploitation and possible protective measure. ICNAF Sel. Pap., 4: 7-14.

COLBOURNE, E., B. DEYOUNG, S. NARAYANAN, and J. HELBIG. 1997. Comparison of hydrography and circulation on the Newfoundland Shelf during 19901993 with the long-term mean. Can. J. Fish. Aquat. Sci., 54(Suppl. 1): 68-80.

DOUBLEDAY, W. G. [ed.] 1981. Manual on groundfish surveys in the Northwest Atlantic. NAFO Sci. Coun. Studies, 2: 7-55.

DRINKWATER, K. F. 1996. Atmospheric and oceanic variability in the northwest Atlantic during the 1980s and early 1990s. J. Northw. Atl. Fish. Sci., 18: 77-97.

DUTIL, J.-D., M. CASTONGUAY, D. GILBERT, and D. GASCON. 1999. Growth, condition, and environmental relationships in Atlantic cod (Gadus morhua) in the northern Gulf of St. Lawrence and implications for management strategies in the Northwest Atlantic. Can. J. Fish. Aquat. Sci., 56: 1818-1831.

DUTIL, J.-D., and Y. LAMBERT. 2000. Natural mortality from poor condition in Atlantic cod (Gadus morhua). Can. J. Fish. Aquat. Sci., 57: 826-836.

GAVARIS, S. 1980. Use of a multiplicative model to estimate catch rate and effort from commercial data. Can. J. Fish. Aquat. Sci., 37: 2272-2275.

GOMES, M. C., R. L. HAEDRICH, and M. G. VILLAGARCIA. 1995. Spatial and temporal changes in the groundfish assemblages on the northeast Newfoundland/Labrador shelf, north-west Atlantic, 1978-1991. Fish. Oceanogr., 4: 85-101.

HAMMILL, M. O., and G. B. STENSON. MS 1997. Estimated prey consumption by harp seals (Phoca groenlandica), grey seals (Halichoerus grypus), 
harbour seals (Phoca vitulina) and hooded seals (Cystophora cristata) in the Northwest Atlantic. NAFO SCR Doc., No. 40, Serial No. N2872, 37 p.

HUTCHINGS, J. A., and R. A. MYERS. 1994. What can be learned from the collapse of a renewable resource? Atlantic cod, Gadus morhua, of Newfoundland and Labrador. Can. J. Fish. Aquat. Sci., 51: 2126-2146.

JAKOBSSON, J., and G. STEFÁNSSON. 1998. Rational harvesting of the cod-capelin-shrimp complex in the Icelandic marine ecosystem. Fish. Res., 37: 7-21.

KULKA, D. W. MS 1998. SPANdex - SPANS geographic information system process manual for creation of biomass indices and distributions using potential mapping. DFO Can. Stock Assess. Sec. Res. Doc., No. $60,28 \mathrm{p}$.

KULKA, D. W., and J. R. FIRTH. 1987. Observer program training manual - Newfoundland Region. Can. Tech. Rep. Fish. Aquat. Sci., No. 1355 (Revised), 197 p.

KULKA, D. W., J. S. WROBLEWSKI, and S. NARAYANAN. 1995. Recent changes in the winter distribution and movements of northern Atlantic cod (Gadus morhua Linnaeus, 1758) on the NewfoundlandLabrador Shelf. ICES J. Mar. Sci., 52: 889-902.

LILLY, G. R. 1987. Interactions between Atlantic cod (Gadus morhua) and capelin (Mallotus villosus) off Labrador and eastern Newfoundland: a review. Can. Tech. Rep. Fish. Aquat. Sci., 1567: vii +37 p.

1991. Interannual variability in predation by cod (Gadus morhua) on capelin (Mallotus villosus) and other prey off southern Labrador and northeastern Newfoundland. ICES Mar. Sci. Symp., 193: 133-146.

LILLY, G. R., M. A. ALMEIDA, and W. H. LEAR. MS 1984. Food of Atlantic cod (Gadus morhua) from southern Labrador and eastern Newfoundland (Div. 2J, 3K, and 3L) in winter. NAFO SCR Doc., No. 88, Serial No. N878, 9 p.

LILLY, G. R., and J. R. BOTTA. MS 1984. Food of Atlantic cod (Gadus morhua L.) near Bonavista, Newfoundland in 1983. NAFO SCR Doc., No. 51, Serial No. N838, 8 p.

LILLY, G. R., D. G. PARSONS, and P. J. VEITCH. 1998. Spatial structure of northern shrimp (Pandalus borealis) off Labrador and eastern Newfoundland (Northwest Atlantic). In: Proceedings of the North Pacific Symposium on Invertebrate Stock Assessment and Management, G.S. Jamieson and A. Campbell (ed.). Can. Spec. Publ. Fish. Aquat. Sci., 125: 265-271.

Lilly, G. R., P. A. SHELTON, J. BRATtEY, N. G. CADIGAN, E. F. MURPHY, and D. E. STANSBURY. MS 1999. An assessment of the cod stock in NAFO Divisions 2J+3KL. NAFO SCR Doc., No. 28, Serial No. N4084, 141 p.

LILLY, G. R., P. A. SHELTON, J. BRATTEY, N. CADIGAN, E. F. MURPHY, D. E. STANSBURY, M. B. DAVIS, and M. J. MORGAN. MS 1998. An assessment of the cod stock in NAFO Divisions $2 \mathrm{~J}+3 \mathrm{KL}$. NAFO SCR Doc., No. 46, Serial No. N3037, 94 p.

MAGNÚSSON, K. G., and Ó. K. PÁLSSON. 1989. Trophic ecological relationships of Icelandic cod. ICES Rapp. Proc.-Verb, 188: 206-224.
McCALLUM, B. R., and S. J. WALSH. 1997. Groundfish survey trawls used at the Northwest Atlantic Fisheries Centre, 1971 to present. NAFO Sci. Coun. Studies, 29: 93-104.

MEHL, S. 1989. The Northeast Arctic cod stock's consumption of commercially exploited prey species in 1984-1986. ICES Rapp. Proc.-Verb, 188: 185-205.

MONTEVECCHI, W. A., and R. A. MYERS. 1996. Dietary changes of seabirds indicate shifts in pelagic food webs. Sarsia, 80: 313-322.

NARAYANAN, S., J. CARSCADDEN, J. B. DEMPSON, M. F. O'CONNELL, S. PRINSENBERG, D. G. REDDIN, and N. SHACKELL. 1995. Marine climate off Newfoundland and its influence on Atlantic salmon (Salmo salar) and capelin (Mallotus villosus). In: Climate change and northern fish populations, R. J. Beamish (ed.). Can. Spec. Publ. Fish. Aquat. Sci., 121: 461-474.

PARSONS, D. G., and E. B. COLBOURNE. 2000. Forecasting fishery performance for northern shrimp (Pandalus borealis) on the Labrador Shelf (NAFO Divisions 2HJ). J. Northw. Atl. Fish. Sci., 27: 11-20.

PARSONS, D. G., E. B. COLBOURNE, G. R. LILLY, and D. W. KULKA. 1998. Northern shrimp (Pandalus borealis) on Flemish Cap (NAFO Division 3M) oceanography, fishery and biology. J. Northw. Atl. Fish. Sci., 24: 1-26.

PARSONS, D. G., R. E. CRAWFORD, L. SAVARD, and E. L. DALLEY. MS 1991. Aspects of the distribution and behaviour of northern shrimp (Pandalus borealis) affecting survey design and stock assessment. ICES C. M. Doc., No. K:42, 10 p.

PARSONS, D. G., G. R. LILLY, and G. J. CHAPUT. 1986. Age and growth of northern shrimp Pandalus borealis off northeastern Newfoundland and southern Labrador. Trans. Amer. Fish. Soc., 115: 872-881.

PARSONS, D. G., and P. J. VEITCH. MS 1991. Assessment of the northern shrimp fishery from northeastern Newfoundland to southern Davis Strait (Divisions 3K to 0B). Can. Atl. Fish. Sci. Adv. Comm. Res. Doc., No. 64, $50 \mathrm{p}$.

PARSONS, D. G., P. J. VEITCH, and G. T. EVANS. MS 1999. Resource status of northern shrimp (Pandalus borealis) off Baffin Island, Labrador and northeastern Newfoundland - second interim review. DFO Can. Stock Assess. Sec. Res. Doc., No. 99/112, 53 p.

PETRIE, B., S. AKENHEAD, J. LAZIER, and J. LODER. 1988. The cold intermediate layer on the Labrador and Northeast Newfoundland Shelves, 1978-86. NAFO Sci. Coun. Studies, 12: 57-69.

PONOMARENKO, I. Ya., and N. A. YARAGINA. MS 1984. Seasonal, local and year-to-year variations in the feeding of Barents Sea cod on shrimp. ICES C. M. Doc., No. G:7.

ROse, G. A., B. deYOUNG, D. W. KulKA, S. V. GODDARD, and G. L. FLETCHER. 2000. Distribution shifts and overfishing the northern cod (Gadus morhua): a view from the ocean. Can. J. Fish. Aquat. Sci., 57: 644-663. 
SANDEMAN, E. J. MS 1978. Shrimp (Pandalus borealis) in the Labrador area-A first assessment. Can. Atl. Fish. Sci. Adv. Comm. Res. Doc., No. 1,14 p.

Dos SANTOS, J., and M. JOBLING. 1995. Test of a food consumption model for the Atlantic cod. ICES J. Mar. Sci., 52: 209-219.

SHELTON, P. A., and G. R. LILLY. 2000. Interpreting the collapse of the northern cod stock from survey and catch data. Can. J. Fish. Aquat. Sci., (in press).

SHELTON, P. A., G. R. LILLY, and E. COLBOURNE. 1999. Patterns in the annual weight increment for Div. $2 \mathrm{~J}+3 \mathrm{KL}$ cod and possible prediction for stock projection. $J$. Northw. Atl. Fish. Sci., 25: 151-159.

SIDORENKO, I. N. 1962. Feeding of cod in western Greenland waters. In: Soviet Fisheries Investigations in the Northwest Atlantic, Y. Y. Marti (ed.). VNIROPINRO, Moskva. p. 249-255. (Transl. from Russian for U.S. Dep. Int., Nat. Sci. Found., Washington, D.C., by Israel Prog. Sci. Transl. 1963).

SMITH, E. H., F. M. SOULE, and O. MOSBY. 1937. The Marion and General Greene expeditions to Davis Strait and Labrador Sea, 1928-1935. Scientific results, part 2: Physical oceanography. U.S. Treasury Dept., Coast Guard Bull., 19: 1-259.

STEFÁNSSON, G., U. SKÚLADÓTTIR, and B. Æ. STEINARSSON. 1998. Aspects of the ecology of a Boreal system. ICES J. Mar. Sci., 55: 859-862.

STENSON, G. B., B. HEALY, P. A. SHELTON, and B. SJARE. MS 1999. Recent trends in the population of Northwest Atlantic harp seals, Phoca groenlandica. NAFO SCR Doc., No. 26, Serial No. N4082, 18 p.

WARREN, W. G., G. R. LILLY, and P. A. SHELTON. MS 1994. Estimating the population mean stomach content weight of cod from a stratified-random trawl survey and length stratified stomach sampling. ICES C. M. Doc., No. D:13, 12 p. 
